\title{
Intravitreal injection of ranibizumab for foveal-macular pattern dystrophy: case report
}

\author{
Injeção intravítrea de ranibizumabe para distrofia foveal-macular em padrão: relato de caso
}

\author{
Alexandre Augusto Cabral de Mello Ventura ${ }^{1}$, Lorna Winifred Grant² ${ }^{2}$, Hajir Dadgostar $^{2}$, Hilel Lewis ${ }^{2}$
}

\begin{abstract}
In the recent years, anti-angiogenic medications have successfully treated other diseases associated with choroidal neovascularization. The anti-angiogenic therapy alone or combined with LASER and/or steroids has been effective in controlling ocular neovascularization, not only restricted to the treatment of typical membranes due to macular degeneration in the wet form. The discovery and subsequent use of these drugs has revolutionized medicine and ophthalmology. This report illustrates an example of successful treatment in a challenging pathology where it was found important visual and anatomical response after the use of ranibizumab.
\end{abstract}

Keywords: Fovea centralis; Lutein; Retinal pigments; Tomography, optical coherence; Macula lutea; Macular degeneration; Fluorescein angiography; Choroidal neovascularization; Antibodies, monoclonal/therapeutic use; Intravitreal injections

\section{RESUMO}

Nos últimos anos, os medicamentos antiangiogênicos têm tratado com sucesso outras doenças relacionadas com a neovascularização da coroide. A terapia antiangiogênica isoladamente ou combinada com LASER e/ou esteroides têm se mostrado eficaz no controle da neovascularização ocular, não se restringindo apenas ao tratamento das membranas típicas da degeneração macular na forma úmida. A descoberta eo posterior uso destas drogas vêm revolucionando a medicina e a oftalmologia. Este relato ilustra um exemplo de tratamento de sucesso numa patologia desafiadora onde se obteve importante resposta visual e anatômica após uso do ranibizumabe.

Descritores: Fóvea central; Luteína; Pigmentos da retina; Tomografia de coerência óptica; Macula lútea; Degeneração macular; Angiofluoresceinografia; Neovascularização de coroide; Anticorpos monoclonais; Injeções intravitreas

\section{INTRODUCTION}

Foveal-macular pattern dystrophies (FMPD) are a group of autosomal dominant disorders that involve degeneration of the retinal pigment epithelium (RPE). In the presence of choroidal neovascularization (CNV) these macular patterns are often confused with age-related macular degeneration (AMD) $)^{(1)}$.In 2007 a case was reported in using intravitreal bevacizumab which yielded only visual acuity stabilization ${ }^{(2)}$. We report the first case of FMPD in which visual acuity and morphologic disease improved after treatment with intravitreal ranibizumab.

\section{CASE REPORT}

A 59-year-old Caucasian woman with fundus changes in her right eye was referred to our clinic for evaluation of AMD. Ocular history included macular photocoagulation for presumed AMD in her left eye. Family history was positive for adult-onset foveal-macular pattern dystrophy inherited in an autosomal dominant pattern (Figure 1 A). Best-corrected visual acuity (BCVA) was 20/30 in her right eye and 20/400 in the left. Fundoscopy revealed foveal-macular pattern dystrophy in the right eye and a fibrovascular membrane secondary to macular photocoagulation in the left eye. Fluorescein angiography (FA) and optical coherence tomography (OCT) of the right eye showed subretinal hemorrhage and early hyperfluorescence with progressive leakage likely representing para-foveal CNV (Figure 2). This eye was then treated with intravitreal injections of bevacizumab for three consecutive months. When her visual acuity continued to decline to 20/50, laser photocoagulation was performed. Two months later her vision stabilized to 20/40. At that time her first intravitreal injection of ranibizumab was administered.

One month after ranibizumab injection BCVA in the right eye improved to 20/30. Exams showed no subsensory fluid and an area of leakage representing either atrophy of the choriocapillaris or persistent neovascularization. Eight months after injection BCVA was 20/20 in the right eye and subsensory fluid remained absent. Over the next six months BCVA declined again to 20/40. Two more injections of ranibizumab were administered and vision returned to $20 / 25$ (Figure 1B).

\section{DISCUSSION}

Foveal-macular pattern dystrophy represents a type of heredodystrophic disorder affecting the pigment epithelium and retina ${ }^{(1)}$. Treatment of these diseases has always been challenging. Previous therapies for FMPD have included laser photocoagulation, photodynamic therapy, and steroids with only visual acuity stabilization $n^{(3-5)}$. In the recent years, the anti-angiogenic medications have successfully treated other CNV-related diseases ${ }^{(6)}$.

This is the first report of using ranibizumab to treat FMPD and visual improvement in FMPD after an antiangiogenic medication. Interestingly this patient's visual acuity declined after treatment with bevacizumab, but improved substantially after ranibizumab injection. Of note, laser photocoagulation was performed two months prior to the first ranibizumab injection. Thus, possibly laser and ranibizumab work additively or synergistically to improve vision. It is unlikely that the improvement from months 6-16 was due solely to the laser since vision also improved after the second dose of
Funding: No specific financial support was available for this study.

Disclosure of potential conflicts of interest: A.A.C.M.Ventura, None; L.W.Grant, None; H.Dadgostar, None; H.Lewis, None.

Correspondence address: Alexandre A.C.M. Ventura. Estrada do Encanamento, 909 - Recife (PE) 52070-000 - Brazil - E-mail: alexandreventura@hotmail.com 


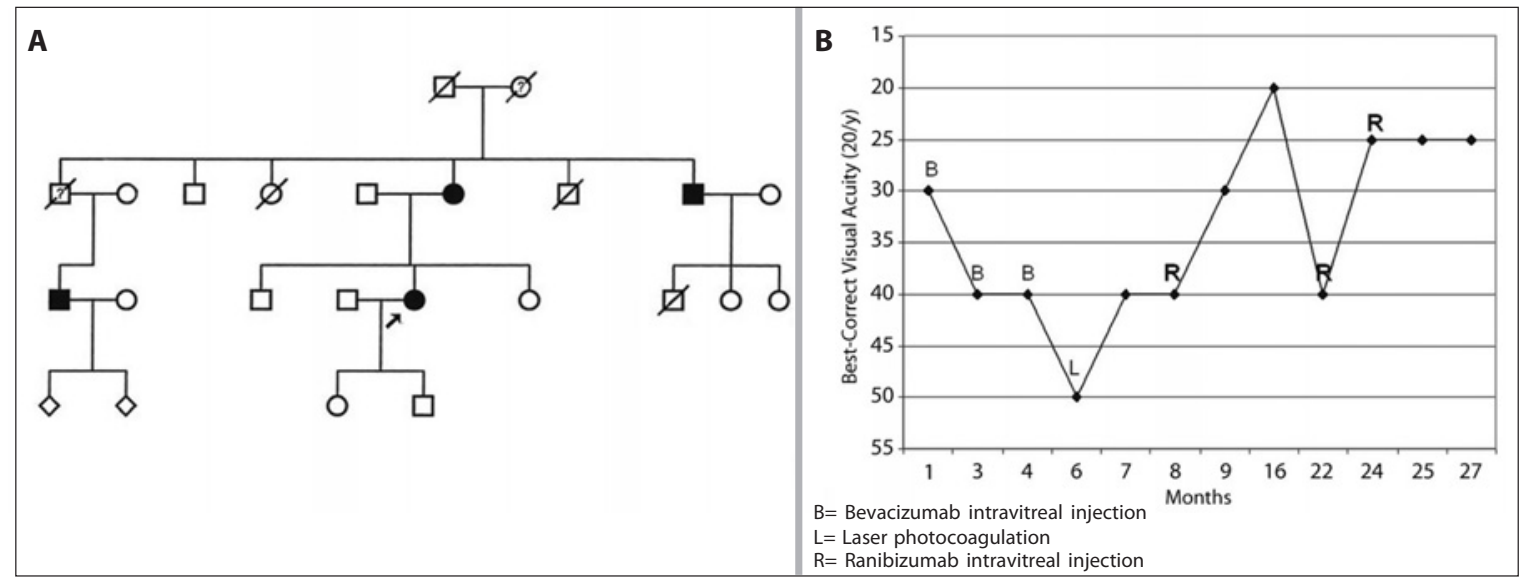

Figure 1. A) Autosomal dominant inheritance foveal-macular pattern dystrophy. The arrow indicates the patient described in this case. Relatives affected by this disease are shown with solid fill; B) Visual improvement after ranibizumab injection. Best-corrected visual acuity (BCVA) testing shows a 3 line increase 1 month after the first injection of ranibizumab. After the second injection of ranibizumab VA improves 2 lines.
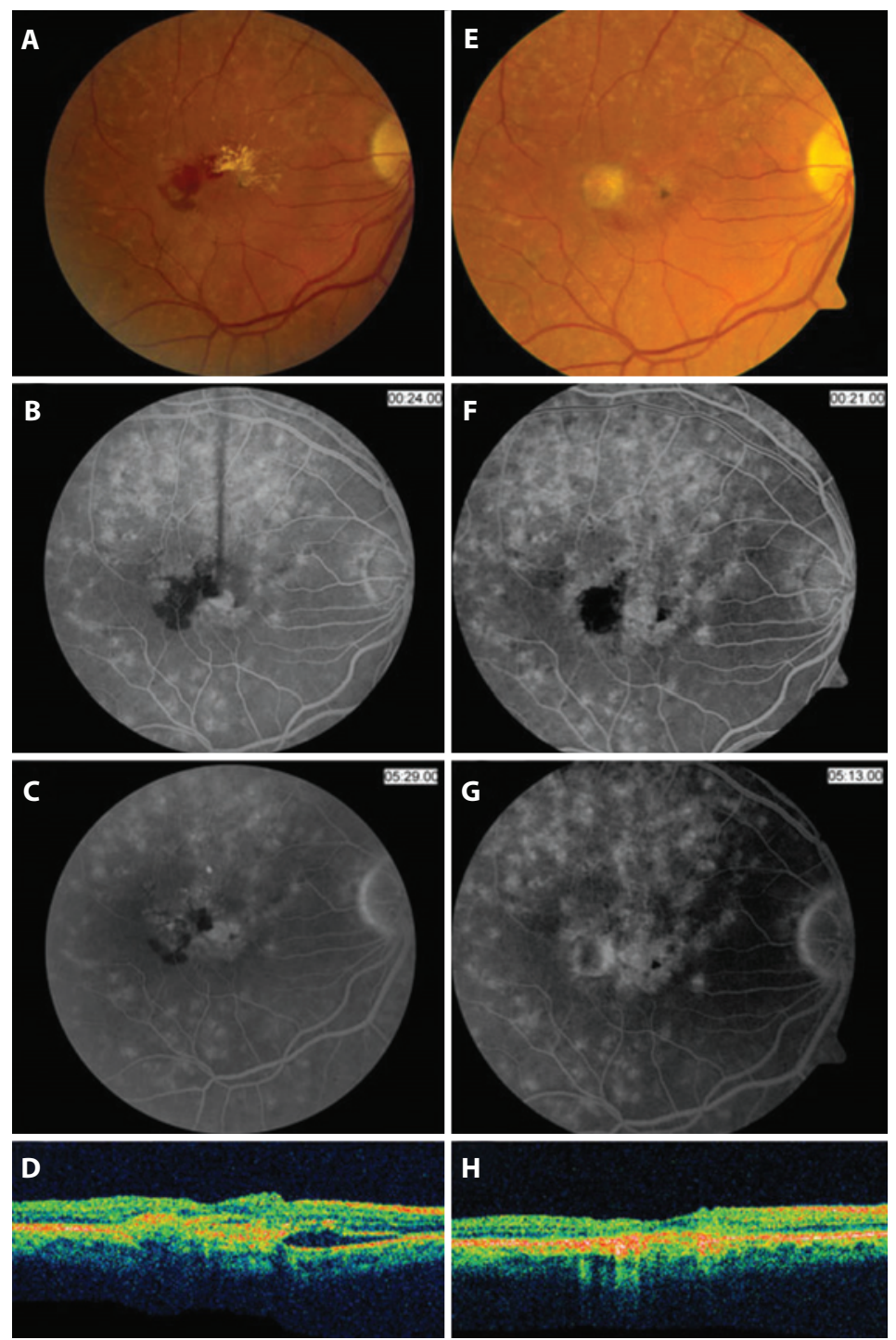

Figure 2. Morphologic improvement post ranibizumab injection. A-C) Red-free retinography (RFR) and fluorescein angiography (FA) before injection show subretinal hemorrhage and fovealmacular lesions with progressive hyperfluorescence.D) Optical coherencetomography (OCT) prior to injection reveals subretinal fluid (SRF). E-G) RFR and FA show disappearance of lesions and leakage, and a disciform scar 1 month after injection. H) OCT 1 month after injection with absence of SRF. 
ranibizumab given alone (Figure 1B). In conclusion, in this patient with FMPD, intravitreal ranibizumab had a therapeutic effect indicated by improved VA and anatomic disease either independent of, or augmented by, prior laser photocoagulation. Further case series are needed to confirm this effect.

\section{REFERENCES}

1. Gass JDM. Pattern dystrophies of the RPE: adult-onset foveomacular vitelliform dystrophy. In: Donald J, Gass M. Stereoscopic atlas of macular diseases: diagnosis and treatment St Louis, Mo: CV Mosby; 1997. p.316-21.
2. Montero, JA, Ruiz-Moreno JM, De La Vega C. Intravitreal bevacizumab for adult-onset vitelliform dystrophy: a case report. Eur J Ophthalmol. 2007;17(6):983-6.

3. Ergun E, Costa D, Slakter J, Yannuzzi LA, Stur M. Photodynamic therapy and vitelliform lesions. Retina. 2004;24(3):399-406

4. Glacet-Bernard A, Soubrane G, Coscas G. [Macula vitellifrom degeneration in adults. Retrospective sudy of a series of 85 patients]. J Fr Ophtalmol. 1990;13(8-9):407-20. French.

5. Braun B, Schneider U, Hasler P. Prünte C. Combination therapy of PDT and triamcinolone in CNV associated with fundus flavimaculatus. Klin Monatsbl Augenheilkd. 2007;224(4): 353-5.

6. Heier JS, Antoszyk AN, Pavan PR, Leff SR, Rosenfeld PJ, Ciulla TA, et al. Ranibizumab for treatment of neovascular age-related macular degeneration: a phase I/II multicenter, controlled, multidose study. Ophthalmology. 2006;113(4):633-42.

\section{Simpósio Internacional Moacyr Álvaro - SIMASP}

\section{8 a 10 de março de 2012 \\ Maksoud Plaza Hotel \\ São Paulo - SP}

\section{Informações:}

Meeting Eventos

Tels.: (11) 3849-8263/3849-0379

Site: http://www.oftalmo.epm.br/simasp2012 